\title{
KONTEKSTUAL CODE SWITCHING DALAM SEMINAR PROPOSAL PROGRAM STUDI PENDIDIKAN BAHASA INGGRIS
}

\author{
Rakhmat Wahyudin Sagala ${ }^{1}$, Tri Indah Rezeki ${ }^{2}$ \\ ${ }^{1}$ Program Studi Pendidikan Bahasa Inggris, Universitas Muhammadiyah Sumatera Utara \\ ${ }^{2}$ Program Studi Pendidikan Bahasa Inggris, STKIP Budidaya Binjai \\ Penulis koresponden: nuansa.bimbel@gmail.com
}

\begin{abstract}
ABSTRAK
Studi ini bertujuan untuk mengetahui fenomena kontekstual code switching yang terjadi didalam proses seminar proposal Program Studi Bahasa Inggris Sekolah Tinggi Keguruan dan Ilmu Pendidikan (STKIP) Budidaya Binjai. Adapun ruang lingkupnya adalah; (1) jenis kontekstual code switching yang digunakan oleh dosen dan mahasiswa bahasa Inggris (2) faktor penentu kontekstual code switching yang dilakukan dosen dan mahasiswa didalam proses seminar proposal Program Studi Pendidikan Bahasa Inggris STKIP Budidaya Binjai. Penelitian ini mengambil data dari tuturan dosen dan mahasiswa selama proses seminar proposal Program Studi Pendidikan Bahasa Inggris dan data diperoleh melalui observasi, wawancara, rekaman dan catatan lapangan. Dari hasil temuan dapat disimpulkan bahwa code switching terjadi dalam tuturan selama proses seminar proposal Program Studi Pendidikan Bahasa Inggris STKIP Budidaya Binjai. Jenis kontekstual code switching yang terdapat dalam tuturan berdasarkan teori Hudson (1996) yaitu Situational code switching dan Metaphorical code switching. Dari temuan diperolah bahasa yang digunakan selama proses seminar proposal adalah bahasa Indonesia dan bahasa Inggris. Dari hasil penelitian juga disimpulkan bahwa faktor penentu dosen dan mahasiswa melakukan code switching adalah karena perubahan situasi tutur, kehadiran orang ketiga dan peralihan pokok pembicaraan.
\end{abstract}

\section{Kata Kunci: Code Switching, Kontekstual Code Switching, Faktor Penentu Code Switching}

\section{PENDAHULUAN}

Sumarsono (2004:201) mengatakan ada tiga jenis pilihan bahasa yang dikenal dalam kajian sosiolinguistik, yaitu alih kode (code switching), campur kode (code mixing) dan variasi dalam bahasa yang sama (variation within the same language). Dari ketiga jenis pilihan bahasa tersebut, dalam penelitian ini hanya membahas satu jenis pilihan bahasa, yaitu alih kode (code switching). Code switching bukan hanya merupakan sebuah fenomena didalam sebuah masyarakat dimana setiap anggotanya menggunakan lebih dari satu bahasa, akan tetapi juga merupakan sebuah kebutuhan di dalam masyarakat tersebut. Code switching digunakan untuk memenuhi "sense" dari pemakainya. Ketika bahasa yang digunakan seseorang dalam menyampaikan pesan dirasakan kurang berhasil atau gagal, orang tersebut perlu merubah bahasanya dengan bahasa yang dipahami. 
Code switching sering terjadi di dalam percakapan sehari-hari yang digunakan pembicara dan dapat terjadi di antara kalimat dalam percakapan antara pembicara dan pendengar, bisa pula di pertengahan kalimat percakapan pembicara dan pendengar.

Pada umumnya, Code Switching sering terjadi di lingkungan pendidikan, termasuk di Perguruan Tinggi Program Studi Pendidikan Bahasa Inggris, hal ini dikarenakan Bahasa Inggris bukan bahasa pertama dosen dan mahasiswa sehingga untuk memudahkan berkomunikasi terkadang mereka melakukan code switching di dalam percakapannya yang berhubungan dengan kegiatan dalam Program Studi Pendidikan Bahasa Inggris. Dalam hal ini, peneliti fokus terhadap code switching yang terjadi di dalam proses seminar proposal Program Studi Pendidikan Bahasa Inggris STKIP Budidaya Binjai ketika mereka sedang berinteraksi.

Berdasarkan observasi yang dilakukan peneliti, dosen cenderung melakukan code switching untuk membantu mahasiswa agar komunikasi tetap berlangsung. Sementara mahasiswa cenderung melakukan code switching karena kurangnya pengetahuan mereka tentang bahasa yang mereka gunakan.

Penelitian ini menganalisis kontekstual code-switching yang terjadi di dalam proses seminar proposal Program Studi Pendidikan Bahasa Inggris Sekolah Tinggi Keguruan dan Ilmu Pendidikan (STKIP) Budidaya Binjai. Penelitian ini berusaha mendeskripsikan faktor-faktor penentu yang menyebabkan terjadinya code switching. Adapun masalah yang teridentifikasi sebagai berikut: 1) Fenomena kontekstual code switching didalam proses seminar proposal Program Studi Pendidikan Bahasa Inggris STKIP Budidaya Binjai; 2) Jenis kontekstual code switching yang digunakan; 3) Faktor penentu code switching dalam seminar proposal bahasa Inggris.

Rumusan masalah dalam penelitian ini adalah penggunaan kontekstual code switching yang dilakukan dosen dan mahasiswa dalam seminar proposal Program Studi Pendidikan Bahasa Inggris STKIP Budidaya Binjai, jenis-jenis kontekstual code switching dan faktor-faktor penentu code switching dalam seminar proposal Program Studi Pendidikan Bahasa Inggris STKIP Budidaya Binjai.

\section{METODE}

Subjek penelitian atau informan penelitian ini adalah dosen penguji dalam seminar proposal program studi Pendidikan Bahasa Inggris dan mahasiswa Program Studi Pendidikan Bahasa Inggris sebagai peserta dalam seminar proposal.

Penelitian ini menggunakan deskriptif kualitatif dimana data diperoleh dari penelitian berupa tuturan atau percakapan antara dosen dan mahasiswa dalam seminar proposal Porgram Studi Bahasa Inggris serta faktor-faktor penentu terjadinya code switching dalam tuturan pada seminar proposal Program Studi Pendidikan Bahasa Inggris STKIP Budidaya Binjai.

Dalam penelitian ini yang menjadi instrumen penelitian adalah peneliti sendiri (Sugiyono, 2008:8). Peneliti melakukan validasi sebelum terjun ke lapangan penelitian dengan melakukan persiapan meliputi pemahaman metode penelitian kualitatif deskriptif dan penguasaan teori mengenai objek yang diteliti yaitu Code Switching dalam seminar proposal 
Prodi Pendidikan Bahasa Inggris. Dalam mengumpulkan data, peneliti menggunakan alat bantu berupa observasi, wawancara, buku catatan dan alat perekam untuk memudahkan peneliti dalam melakukan pengumpulan data. Teknik yang digunakan untuk mengumpulkan data dalam penelitian ini adalah dengan wawancara, observasi dan dokumentasi.

\section{HASIL DAN PEMBAHASAN}

Setelah mengumpulkan dan mentranskip data bagaimana dosen penguji dan mahasiswa peserta seminar proposal menggunakan alih kode dari satu bahasa ke bahasa lain, jenis alih kode dianalisis berdasarkan teori Hudson (1996) yaitu Situational code switching dan metaphorical code switching. Dari data diperoleh:

Tabel 4.1. Hasil Analisis Data

\begin{tabular}{ccc}
\hline \multirow{2}{*}{$\begin{array}{c}\text { Jadwal Seminar } \\
\text { Proposal }\end{array}$} & \multicolumn{2}{c}{ Jenis Kontekstual Code Switching } \\
\cline { 2 - 3 } & $\begin{array}{c}\text { Situational Code } \\
\text { Switching }\end{array}$ & $\begin{array}{c}\text { Metaphorical Code } \\
\text { Switching }\end{array}$ \\
\hline 19 Maret 2018 & 84 & 5 \\
\hline TOTAL & 84 & 5 \\
\hline
\end{tabular}

Table 4.1 menunjukkan bahwa terdapat 84 tuturan yang menunjukkan situational code switching dimana terdapat perubahan situasi secara sadar yang membuat mereka melakukan code switching tanpa mengganti topik pembicaraan dan 5 tuturan yang menunjukkan metaphorical code switching dimana pembicara merubah topik pembicaraan dari formal ke informal dan sebaliknya, Berikut adalah contoh percakapan yang mengandung code switching berdasarkan hasil data:

Tabel 4.2. Ekspresi Situational Code Switching

\begin{tabular}{|c|c|}
\hline No & Ekspresi \\
\hline & Well, apa research problem kamu? \\
\hline & $\begin{array}{l}\text { My research problem is untuk mencari pengaruh metode Semantic Mapping terhadap } \\
\text { writing descriptive }\end{array}$ \\
\hline & So, menurut kamu apakah metode tersebut appropriate dengan writing descriptive? \\
\hline & I think yes. karena metode ini memudahkan siswa dalam menulis paragraf descriptive \\
\hline & What is your research design? Jelaskan apa desain penelitian kamu \\
\hline & Desain penelitian saya adalah quantitative experiment \\
\hline & Apa itu quantitative experiment? \\
\hline & Membandingkan dua kelas experimental and control group \\
\hline & What is your data? Apa populasinya? \\
\hline & The data is dari teks deskriptif yang dikerjakan siswa. \\
\hline & The population is kelas eleventh SMAN Bahorok \\
\hline & Kenapa kamu melakukan research ini? \\
\hline & Karena research ini penting untuk membantu siswa meningkatkan writing ability \\
\hline & $\begin{array}{l}\text { What do you know about narrative text? Pernah tidak kamu aplikasikan metode ini dalam } \\
\text { mengajar teks naratif? }\end{array}$ \\
\hline
\end{tabular}


Narrative text is teks yang menceritakan peristiwa lampau seperti dongeng, mitos, legenda.

16 Good. How will you teach students a narrative text. Bagaimana cara kamu memberi pemahaman narrative text kepada siswa

17 I give question berupa soal-soal multiple choice atau pilihan ganda

${ }_{18}$ Ok. But not just that one. Kamu harus memberikan soal yang lebih qualified lagi in order to measure the students' competence in writing. Paham maksudnya kan?

19 Yes sir. Berarti untuk memberikan penilaian dalam kemampuan writing multiple choice itu kurang ya sir?

20 Yes, that's right. Lebih bagus untuk mengukur kemampuan writing narrative text siswa,

${ }^{20}$ kamu buat sebuah teks yang menuntut siswa menganalisis sebuah teks. For instance, you provide some of texts that consist narrative, procedure and spoof. Lalu

21 kamu suruh mereka menentukan dari ketiga teks itu mana yang narrative beserta generic structure nya.

22 Penelitian you tentang reading comprehension

23 Can you explain what is your problem? Coba jelaskan dulu masalah penelitian kamu

24 There are four skills in English yaitu speaking, listening, reading and writing.

25 Diantara 4 skill tersebut reading comprehension adalah salah satu skill yang membebani

25 siswa. And so that is my research problem.

${ }_{26}$ Ok then, what will you do in that problem. Artinya apa yang akan kamu lakukan nanti dengan masalah seperti itu.

27 Ya itu mom, memberikan tugas kepada siswa dalam bentuk multiple choice

${ }_{28}$ Apa kamu yakin? Do you think that multiple choice suitable to measure students' reading comprehension?

29 I think yes mom. Karena yang mau dilihat kemampuan reading nya 30 Menurut saya, to measure reading comprehension siswa harus diberikan teks untuk membaca

31 Yes mom. Jadi kalau begitu multiple choice nggak bisa ya mom?

32 Ya kamu harus cari teks dan itu disesuaikan dengan kurikulum. So, your research can

32 solve the problem.

OK Saora, open page four. I think you have so many the significance of the study. There are six right? So which problem that you find out in MAS Adrasah? The big problems of

33 the students that you find. Apa yang kamu temukan. Ini kan nggak asal-asal kamu temukan kan? So you have to do your mini research. Pra ya bukan free. Oh, kalau itu masalah lah disini. So which one is the problem?

34 Problem nya, mereka masih belum bisa gitu mom speak English.

They don't know, so very very big problem. I think you should do long research. Kan to

35 improve speaking ability. Nggak mungkin sekali aja tiba besoknya mereka uda bisa speak English. So, they are difficult to speak. What about grammar? Mereka nggak tau ABCD. So, what do you think?

36 Next, page five. Halaman lima ya. The significance of the study. You should make theoretically. Secara teori itu apa. And then practically, for teachers, students, schools and 
for the other researchers. Tambahkan di proposal kamu. Nanti saya kembalikan sama kamu.

37 Next, what is Boom Card? Kartu Bom itu kan definisinya. What's the meaning Boom card? Ya kartu Boom. Kartu Boom itu apa?

38 Boom card is kartu yang ...

39 Kartu yang apa? Kartu yang bisa meledak gitu? Can you Saora?

40 Can they speak English? Atau pernah kamu practice?

41 Yang harus kamu tambah disitu for general concept of Boom card. Definition nya buat, ini kan teori yang harus kamu kerjakan. Definition nya itu apa? Definition of Boom card.

42 Kemudian advantages dan disadvantages of speaking. Pasti ada kan kelemahannya Kemudian the way you teach speaking. Pasti ada kan step-step kamu mengajarkan game

43 ini. Your own way.jadi tidak lari dari teori si Boom card ini. Apa-apa aja yang kamu lakukan dengan menggunakan game yang ini. Jangan kamu gunakan game yang lain

${ }_{44}$ Jadi speaking nya ini. What kind of topic? Topic nya tentang apa. Apakah free? Tiba-tiba stop dimana, bebas mau ngapain.

${ }_{45}$ Oke next in chapter three. Chapter tiga. Time and location. Time nya sudah ada. Location nya dimana? At the first, make the location

46 Next, population. How many population?

47 Population? Semua kelas?

$48 Y a$, all population. Semua populasinya 205

49 Saora, so many students. So, kamu pilih sample nya bagaimana. Apakah dengan kamu

49 suka atau dengan cara random sampling.

${ }_{50}$ Kan ada kelas yang satu experiment dan yang satu kelas control. Jadi harus menggunakan random sampling

Dari Tabel 4.2 terdapat 50 tuturan yang menunjukkan ekspresi Situational Code Switching dimana penutur menyadari melakukan code switching dengan menggunakan bahasa Inggris dan bahasa Indonesia tanpa mengganti topik pembicaraan. Penutur mengganti bahasa Inggris ke bahasa Indonesia karena perubahan situasi untuk tetap menjaga interaksi atau percakapan antara dosen penguji dan mahasiswa peserta seminar tetap berlangsung.

\section{Tabel 4.3. Ekspresi Methaporical Code Switching}

\begin{tabular}{l}
\hline No \\
\hline 1 Hi. kamu nervous? \\
\hline 2 Yes mom. Indonesia boleh mam? \\
\hline 3 Indonesia? Mixing boleh. Nggak boleh bahasa Indonesia semua
\end{tabular}

Dari Tabel 4.3 terdapat 3 tuturan yang menunjukkan ekspresi Methaporical Code Switching dimana penutur menggunakan code switching karena adanya perubahan atau pergantian topik. Dari ketiga tuturan terlihat bahwa tuturan tersebut tidak berhubungan dengan topik di dalam seminar proposal tetapi penutur mencoba mengalihkan kode sebagai tujuan untuk membuat situasi lebih akrab. 


\subsection{Faktor Penentu Code Switching}

Berdasarkan hasil observasi dan wawancara yang dilakukan kepada informan yaitu dosen penguji dan mahasiswa peserta seminar proposal, faktor penentu code switching adalah karena perubahan situasi, kehadiran orang ketika dan peralihan pokok pembicaraa. Berikut analisis datanya:

\section{Perubahan Situasi Tutur}

Contoh tuturan yang menunjukkan perubahan situasi adalah:

Mahasiswa : Boom card is kartu yang ...

Dosen : Kartu yang apa? Kartu yang bisa meledak gitu? Can you Saora?

Dari tuturan diatas terlihat bahwa penutur (dosen) mengubah dari situasi informal menjadi situasi formal.

\section{Kehadiran orang ketiga}

Dosen dan mahasiswa melakukan code switching karena kehadiran orang ketiga dimana dalam situasi seminar proposal program studi Pendidikan Bahasa Inggris tidak hanya dosen bahasa Inggris yang menjadi penguji tetapi juga terdapat dosen dari program studi lain seperti dosen penguji dari program studi Bahasa Indonesia, Matematika, Bimbingan Konseling dan Kewarganegaraan. Kehadiran dosen-dosen tersebut membuat terjadinya code switching dalam proses seminar proposal di program studi Pendidikan Bahasa Inggris.

\section{Peralihan Pokok Pembicaraan}

Contoh tuturan yang menunjukkan perubahan situasi adalah:

Dosen : $\mathrm{Hi}$, kamu nervous ya? Kenapa kamu melakukan research ini?

Dari tuturan diatas terlihat bahwa terjadi peralihan pokok pembicaraan dari penutur.

\section{Penghargaan}

Penelitian ini dibiayai oleh SIMLITABMAS. Direktorat Riset dan Pengabdian Masyarakat. Direktorat Jenderal Penguatan Riset dan Pengembangan. Kementerian Riset, Teknologi dan Pendidikan Tinggi, sesuai dengan kontrak penelitian tahun anggaran 2018.

\section{SIMPULAN}

Berdasarkan temuan penelitian, dapat disimpulkan bahwa code switching terjadi dalam tuturan selama proses seminar proposal. Jenis code switching yang terdapat dalam tuturan berdasarkan teori Hudson (1996) yaitu Situational Code Switching sebanyak 50 tuturan dan Methaporical code switching sebanyak 3 tuturan. Faktor penentu code switching dosen dan mahasiswa melakukan alih kode adalah karena perubahan situasi tutur, kehadiran orang ketiga dan peralihan pokok pembicaraan.

\section{REFERENSI}


Alwasilah, A. Chaedar. 1993. Pengantar Sosiologi Bahasa. Bandung: Angkasa.

Anwar, Khaidir. 1990. Fungsi dan Peranan Bahasa. Yogyakarta: Gadjah Mada University.

Moleong, Lexy J. 2012. Metodologi Penelitian Kualitatif. Bandung: Remaja Rosdakarya

Nababan, PWJ. 1986. Sosiolinguistik Suatu Pengantar. Jakarta: Gramedia.

Pateda, Mansoer. 1987. Sosiolinguistik. Bandung: Angkasa

Pranowo. 1996. Analisis Pengajaran Bahasa. Yogyakarta: Gajah Mada University Press.

Rahmadani, Safitri. 2011. Alih Kode dan Campur Kode dalam Percakapan dalam Lingkungan Jurusan Bahasa Inggris di Universitas Indonesia. Depok.

Sumarsono. 1993. Pemertahanan Bahasa Melayu Loloan di Bali. Jakarta: Pusat Pengembangan Bahasa. . 2014. Sosiolinguistik. Yogyakarta: Pustaka Pelajar 